\title{
The bZIP Transactivator of Epstein-Barr Virus, BZLF1, Functionally and Physically Interacts with the p65 Subunit of NF-кB
}

\author{
DAVID E. GUTSCH,${ }^{1,2} \dagger$ ELIZABETH A. HOLLEY-GUTHRIE, ${ }^{1}$ QIN ZHANG, ${ }^{1}$ BERND STEIN, ${ }^{1}$ \\ MICHAEL A. BLANAR, ${ }^{3}$ ALBERT S. BALDWIN, ${ }^{1,4}$ AND SHANNON C. KENNEY ${ }^{1,2 *}$ \\ UNC Lineberger Comprehensive Cancer Center, ${ }^{1}$ Department of Medicine, ${ }^{2}$ and Department of Biology, ${ }^{4}$ University of \\ North Carolina at Chapel Hill, Chapel Hill, North Carolina 27599-7295, and Department of Biochemistry and \\ Biophysics, Hormone Research Institute, University of California, San Francisco, California 94143-0534 3
}

Received 20 May 1993/Returned for modification 9 July 1993/Accepted 13 December 1993

\begin{abstract}
The Epstein-Barr virus (EBV) BZLF1 (Z) immediate-early transactivator initiates the switch between latent and productive infection in $B$ cells. The $Z$ protein, which has homology to the basic leucine zipper protein c-Fos, transactivates the promoters of several replicative cycle proteins. Transactivation efficiency of the EBV BMRF1 promoter by $Z$ is cell type dependent. In $B$ cells, in which $E B V$ typically exists in a latent form, $Z$ activates the BMRF1 promoter inefficiently. We have discovered that the p65 component of the cellular factor NF- $\mathrm{NB}$

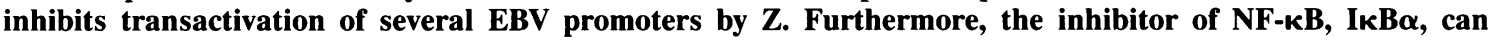
augment $Z$-induced transactivation in the B-cell line Raji. Using glutathione $S$-transferase fusion proteins and coimmunoprecipitation studies, we demonstrate a direct interaction between $Z$ and p65. This physical interaction, which requires the dimerization domain of $Z$ and the Rel homology domain of p65, can be demonstrated both in vitro and in vivo. Inhibition of $Z$ transactivation function by NF-kB p65, or possibly by other Rel family proteins, may contribute to the inefficiency of $Z$ transactivator function in $B$ cells and may be a mechanism of maintaining B-cell-specific viral latency.
\end{abstract}

Epstein-Barr virus (EBV) is a human herpesvirus which infects primarily $B$ cells and epithelial cells (reviewed in reference 33). Infection with EBV is strongly associated with the development of Burkitt's lymphoma in B cells and nasopharyngeal carcinoma (45) in epithelial cells. Infection of normal B cells with EBV results in the establishment of a latent state, with entry into the viral replicative cycle typically occurring in only a very small number of these cells $(33,45)$. In contrast, infection of epithelial cells with EBV results in viral production and shedding into the saliva (66). The BZLF1 (Z) protein is the first productive cycle protein that is expressed during reactivation of viral replication in $B$ cells $(14,15,70)$. The immediate-early $Z$ protein disrupts viral latency through transactivation of early EBV genes which contain upstream Z-binding sites $(9,11,13,14,16,30,31,42,43,64,71)$. $Z$ also can activate its own expression $(19,71)$. Although the $Z$ protein lacks the classic heptad leucine repeats, $\mathrm{Z}$ belongs to the basic leucine zipper (bZIP) family of proteins, containing a basic DNA-binding domain adjacent to a coiled-coil dimerization domain (18). $\mathrm{Z}$ protein structure bears resemblance to the structure of the c-Fos leucine zipper protein (18); however, unlike c-Fos, $\mathrm{Z}$ has not been shown to heterodimerize with any other bZIP protein.

We have shown that some EBV early promoters, such as the BMRF1 (early antigen-diffuse) promoter, are transactivated very poorly by $\mathrm{Z}$ in certain lymphoid cell lines, while in epithelial cell lines, the same promoters are highly $Z$ responsive $(29,53)$. In lymphoid cell lines not supporting efficient $Z$ function, there may exist inhibitors of $Z$ transactivation. One candidate for such a B-cell-specific inhibitor of $\mathrm{Z}$ is the cellular factor NF-kB.

\footnotetext{
* Corresponding author.

$\dagger$ Present address: Department of Internal Medicine, University of Michigan, Ann Arbor, MI 48109.
}

As with Z, constitutive NF-кB function is cell type specific $(39,63)$. Although NF-кB is expressed in many types of cells, in most instances NF- $\kappa$ B is complexed with I $\mathrm{B}$ and held in an inactive state within the cytoplasm (3). In mature B cells, in which NF- $\kappa$ B function regulates the expression of the immunoglobulin kappa protein $(39,63)$, a portion of $N F-\kappa B$ is dissociated from IкB and thus found in the nucleus in an active form (3).

Classic NF- $\mathrm{BB}$ is composed of two proteins, p50 and p65 (4). The p50-p65 complex can bind to NF- $\mathrm{BB}$ sites within certain promoters (63) and activate transcription. These two proteins have been found to have structural similarity to the protein product of the c-rel proto-oncogene and other Rel-like proteins $(21,34,52,57)$. The p50 protein is processed from a larger precursor protein, p105, which contains a series of domains called ankyrin repeats $(21,34)$, and is also closely related to another ankyrin-containing Rel type protein called $\mathrm{p} 100 / \mathrm{p} 52$ (50). The MAD-3 form of ІкB (ІкB $\alpha$ ) contains ankyrin repeats without the Rel homology domain (27). A second group of Rel-like proteins, including p65 $(52,57)$, c-Rel (73), RelB (59), and the Drosophila protein Dorsal (69), all have Rel domains without ankyrin repeats. A newly discovered alternatively spliced form of p65, termed p65 , lacks 10 amino acids within the Rel domain of p65 (58). Overexpression of this naturally occurring variant of p65 in Rat-1 cells produces transformed foci which are tumorigenic in nude mice (48). The complex patterns of heterodimerization between the Rel family members are now being elucidated (reviewed in reference 51). In addition to multimerization between Rel family proteins, interfamily interactions involving Rel proteins exist. Recently, it was found that the p50 and p65 proteins can physically interact with the bZIP protein, NF-IL6 $(38,67)$.

Here we report the physical and functional interaction between a member of the bZIP family of transactivators, Z, and the Rel protein, NF-кB p65. We show that p65 functions 
as an inhibitor of Z-induced transactivation of early EBV promoters and that $\mathrm{Z}$ and $\mathrm{p} 65$ can physically interact with one another both in vitro and in vivo. This ability of p65 to inhibit the function of the EBV protein which triggers disruption of viral latency may partly explain the tendency of EBV infection to remain latent in $\mathrm{B}$ cells.

\section{MATERIALS AND METHODS}

Plasmid constructions. The pEA-BS-CAT construct, which contains the EBV BMRF1 promoter sequences from -331 to +1 linked to the chloramphenicol acetyltransferase (CAT) reporter, has been described elsewhere (32). The pBHRF1CAT plasmid contains a 1,020-bp NaeI-to-HincII fragment of the EBV BHRF1 promoter (26) (EBV positions 52800 to 53819) linked to CAT in the plasmid vector pBS+ (Stratagene). The pHD1013 expression plasmid contains a $2.1-\mathrm{kb}$ Pst I fragment of the cytomegalovirus (CMV) immediate-early promoter/enhancer in the PstI site of pGEM2 (Promega) (30). Plasmid CMV-Z contains the $\mathrm{Z}$ cDNA from plasmid pKSVZ41 (a gift from Alain Sergeant) (22) downstream and under the control of the CMV immediate-early promoter in pHD1013. Construction of the CMV promoter control vector, pCMV4T, has been described elsewhere (72). Plasmids pCMV4T-p65, pCMV4T-p65

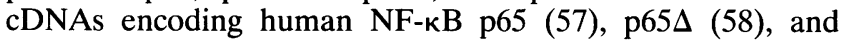
I $\mathrm{B} \alpha / \mathrm{MAD}-3$ (27) inserted into the pCMV4T expression vector (67). Plasmid pGST-Z was created by inserting the cDNA encoding full-length $\mathrm{Z}$ (a gift of Paul Farrell) blunt end and in frame into the SmaI site of pGEX-3X (Pharmacia). Glutathione $S$-transferase (GST) Z $\Delta 1-79$, GST Z $\Delta 1-133$, and GST Z $\Delta 200-227$ contain $Z$ cDNA lacking coding sequence for the amino acid residues indicated by the numbers used to name each plasmid $(22,32)$ (gifts of Alain Sergeant and Frank Furnari) inserted into pGEX-2T (Pharmacia). The GST-p65 construct contains the intact p65 coding sequences downstream of the GST protein (67) in plasmid pGEX-1N (AMRAD Corp.). The Z-containing EcoRI fragment from pKSVZ41 was inserted into a modified pFlag (International Biotechnologies, Inc.) vector (8) to produce pFlag Z. Similarly, a fragment encoding the first 171 amino acids of a $\mathrm{Z}$ cDNA was generated by PCR and inserted into the modified pFlag vector, creating pFlag $\mathrm{Z} \triangle \mathrm{COOH}$. The plasmid for in vitro expression of the wild-type $Z$ protein (a gift of Paul Farrell) and the point mutants of the $\mathrm{Z}$ dimerization domain (a gift of Erik Flemington and Samuel Speck) have been described in detail elsewhere $(20,56)$. Plasmids for in vitro expression of wild-type p65, p65 , and p65 with a four-amino-acid substitution from KRKR to DQNQ in the nuclear localization signal of p65 (p65 $\triangle$ NLS; a gift of Amer Beg) have been described elsewhere (6, 67). The in vitro-translated proteins p65 $\Delta 313$, p $65 \Delta 285$, and p65 $\Delta 196$ were created by runoff transcription ending at $B s p H I$, $E c o$ RI, and $B g l I I$ sites, respectively, within the wild-type p65 reading frame.

DNA preparation and transfections. Plasmid DNA was purified through two sequential cesium chloride gradients. Electroporation of both lymphoid and epithelial cells was performed as previously described $(31,70)$. Approximately 5 $\times 10^{6}$ cells were used for each condition.

Cell lines. P3HR1 and Raji are EBV-positive Burkitt's lymphoma B-cell lines which were maintained in RPMI 1640 medium supplemented with $10 \%$ fetal calf serum. The cervical carcinoma cell line HeLa was grown in Dulbecco modified Eagle medium $\mathrm{H}$ with $5 \%$ fetal calf serum.

CAT assays. Cells were harvested $48 \mathrm{~h}$ after transfection with plasmid DNA. Cell extracts were incubated at $37^{\circ} \mathrm{C}$ with
${ }^{14} \mathrm{C}$-labeled chloramphenicol in the presence of acetyl coenzyme A as previously described (24). The percent acetylation of chloramphenicol was quantitated by thin-layer chromatography, followed by autoradiography and either scintillation or PhosphorImager (Molecular Dynamics) counting. The CAT assays were repeated with less extract if results were not in the linear range (less than $70 \%$ acetylated).

Synthesis and radiolabeling of proteins. Plasmids encoding the GST fusion proteins were introduced into Escherichia coli HB101. An overnight culture was diluted 1:10 in Luria-Bertani broth with ampicillin, grown for $2 \mathrm{~h}$, and then induced with 0.4 $\mathrm{mM}$ isopropyl- $\beta$-thiogalactopyranoside (IPTG) for $2 \mathrm{~h}$ at $37^{\circ} \mathrm{C}$. Bacteria were pelleted and resuspended in $1 / 10$ volume of phosphate-buffered saline (PBS), sonicated, and centrifuged in Eppendorf tubes at $13,000 \mathrm{rpm}$. These supernatants were either used directly for immunoprecipitation or incubated with glutathione (GSH)-agarose beads (Sigma). Swollen GSH-agarose beads were reacted for $20 \mathrm{~min}$ at room temperature with extracts containing the GST proteins at a ratio of $50 \mu \mathrm{l}$ of beads per $\mathrm{ml}$ of extract. The coated beads were then washed three times in Z/p65 buffer ( $20 \mathrm{mM} \mathrm{N}$-2-hydroxyethylpiperazine- $N^{\prime}$-2-ethanesulfonic acid [HEPES; $\mathrm{pH}$ 7.7], $25 \mathrm{mM} \mathrm{NaCl}$, $2.5 \mathrm{mM} \mathrm{MgCl}_{2}, 0.1 \mathrm{mM}$ EDTA, $1 \mathrm{mM}$ dithiothreitol [DTT], $0.05 \%$ Nonidet P-40) and then used in GST precipitation experiments.

The Flag $\mathrm{Z}$ and Flag $\mathrm{Z} \Delta \mathrm{COOH}$ plasmids were introduced into $E$. coli $\mathrm{DH} 5 \alpha \mathrm{F}^{\prime}$ (Gibco BRL), grown to log phase, and induced for $4 \mathrm{~h}$ with IPTG. Proteins were harvested first by incubation in $50 \mathrm{mM}$ Tris- $\mathrm{HCl}$ (pH 8)-1 mM EDTA-100 mM $\mathrm{NaCl}-0.1 \mathrm{mM}$ phenylmethylsulfonyl fluoride-1 $\mathrm{mM}$ sodium metabisulfite $-1 \mathrm{mg}$ of lysozyme per $\mathrm{ml}$. Sodium deoxycholate was added to $16 \mathrm{mg} / \mathrm{ml}$, and the lysates were incubated at $37^{\circ} \mathrm{C}$ for $10 \mathrm{~min}$ and then sonicated. The cellular debris was pelleted at $12,000 \times g$, and the supernatant was dialyzed against $25 \mathrm{mM}$ HEPES-12.5 mM MgCl $2-100 \mathrm{mM} \mathrm{KCl}-30 \mu \mathrm{M}$ phenylmethylsulfonyl fluoride-12.5 $\mu \mathrm{M}$ sodium metabisulfite-1 mM DTT$20 \%$ glycerol and then used directly for ${ }^{32} \mathrm{P}$ labeling. The Flag protein labeling reaction mixture contained $20 \mathrm{mM}$ Tris- $\mathrm{HCl}$ (pH 7.5), $1 \mathrm{mM}$ DTT, $10 \mathrm{mM} \mathrm{NaCl}, 12 \mathrm{mM} \mathrm{MgCl} 2,2 \mu \mathrm{l}$ of $\left[\gamma^{-32}\right.$ P]ATP (Amersham Life Sciences; catalog no. PB.10168), $10 \mathrm{U}$ of heart muscle kinase (Sigma; catalog no. P-2645), and $2 \mu \mathrm{l}$ of crude bacterial extract containing Flag $\mathrm{Z}$ protein in a total volume of $30 \mu \mathrm{l}(8)$. Proteins were labeled at $37^{\circ} \mathrm{C}$ for 1 h. In vitro transcription and translation for ${ }^{35} \mathrm{~S}$ labeling reactions were performed as suggested by the manufacturer (Promega).

GST precipitations. Ten microliters of GST, GST-Z, or GST-p65-coated GSH-agarose beads was incubated with either $10,000 \mathrm{cpm}$ of ${ }^{32} \mathrm{P}$-labeled Flag protein or $10 \mu \mathrm{l}$ of reticulocyte lysate containing ${ }^{35} \mathrm{~S}$-labeled $\mathrm{Z}$ or p65 protein in a $1-\mathrm{ml}$ total volume of $\mathrm{Z} / \mathrm{p} 65$ buffer. Following a $1-\mathrm{h}$ room temperature incubation, the beads were washed five times with $\mathrm{Z} / \mathrm{p} 65$ buffer and boiled in sodium dodecyl sulfate (SDS)polyacrylamide gel electrophoresis (PAGE) loading buffer. The proteins were then separated on a $10 \%$ denaturing polyacrylamide gel and submitted to autoradiography (enhanced with $1 \mathrm{M}$ sodium salicylate for ${ }^{35} \mathrm{~S}$-labeled proteins).

To demonstrate a genuine DNA-independent interaction between $\mathrm{Z}$ and $\mathrm{p} 65$, the crude bacterial extracts containing GST fusion proteins and the reticulocyte lysates containing ${ }^{35} \mathrm{~S}$-labeled proteins were treated with DEAE-Sephacel prior to GST precipitation as previously described (1). As a marker for the removal of nonspecific DNA, protein extracts were spiked with a ${ }^{32} \mathrm{P}$-labeled tracer probe containing the class I major histocompatibility complex NF-кB DNA-binding site (5) 
A

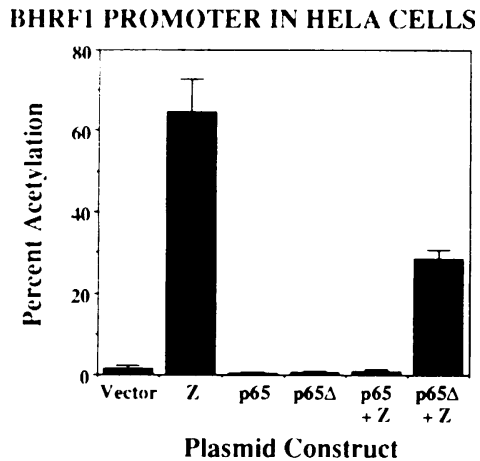

B

BMRF1 PROMOTER IN HELA CELLS

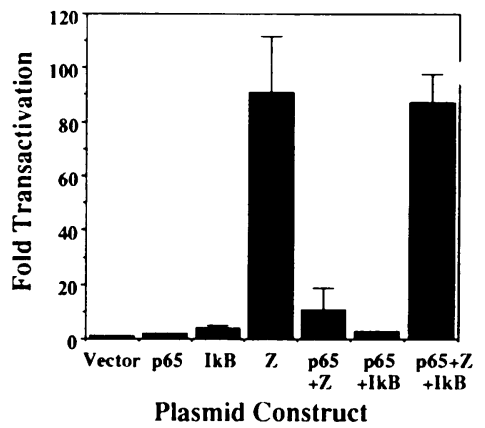

C
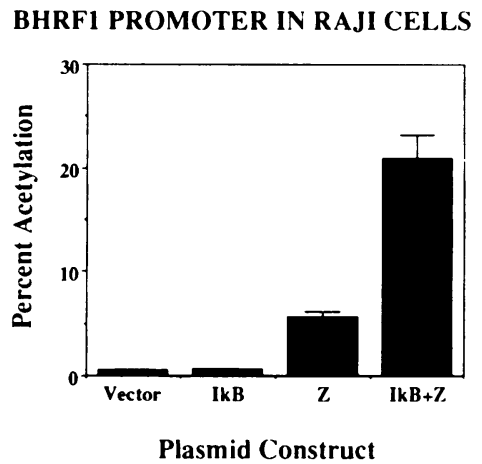

FIG. 1. Z-induced transactivation of several EBV promoters is inhibited by NF-kB p65. (A) Plasmid pBHRF1-CAT (3 $\mu \mathrm{g})$ was transfected into the HeLa epithelial cell line with various combinations of expression plasmids (each at $3 \mu \mathrm{g}$ ) as follows (left to right): pBHRF1-CAT with the vectors pCMV4T and pHD1013; pBHRF1-CAT with pCMV4T and the Z expression vector CMV-Z; pBHRF1-CAT with the p65 expression

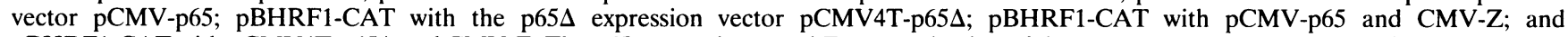
pBHRF1-CAT with pCMV4T-p65 and CMV-Z. The p65 vector decreased Z transactivation of the BHRF1 promoter. Coexpression of p65 $\Delta$ with $\mathrm{Z}$ inhibited $\mathrm{Z}$ transactivation of the BHRF1 promoter only to a moderate degree in comparison with the inhibition of $\mathrm{Z}$ by $\mathrm{p} 65$. (B) The BMRF1-CAT (pEA-BS-CAT) plasmid $(5 \mu \mathrm{g})$ was transfected into the HeLa epithelial cell line with various combinations of expression plasmids (each at $3 \mu \mathrm{g}$ ) as follows (left to right): BMRF1-CAT with the vectors pCMV4T and pHD1013; BMRF1-CAT with pCMV-p65; BMRF1-CAT with the I $\kappa$ B expression vector pCMV4T-I $\kappa$ B; BMRF1-CAT with CMV-Z; BMRF1-CAT with pCMV-p65 and CMV-Z; BMRF1-CAT with pCMV-p65 and pCMV4T-IкB; and BMRF1-CAT with pCMV-p65, CMV-Z, and pCMV4T-IкB. As with the BHRF1 promoter, the p65 vector decreased Z transactivation of the BMRF1 promoter (fifth column). The addition of the IкB expression vector overcame the inhibitory effect of p65 upon Z-induced transactivation of the BMRF1 promoter (seventh column) (C) The BHRF1-CAT plasmid ( $3 \mu \mathrm{g})$ was transfected into the Raji B-cell line with various combinations of expression plasmids (each at $3 \mu \mathrm{g}$ ) as follows (left to right): the vectors pCMV4T and pHD1013; pCMV4T-IkB; pCMV4T and CMV-Z; and pCMV4T-IкB and CMV-Z. Coexpression of I $\mathrm{B}$ with Z increased Z-induced transactivation of BHRF1-CAT fourfold above the level of transactivation due to $\mathrm{Z}$ alone in Raji cells. Error bars indicate the standard error of the mean.

and then equally divided for GST precipitation studies with extracts untreated or treated with DEAE-Sephacel.

Immunoprecipitations and immunoblotting. Approximately $10^{7} \mathrm{HeLa}$ cells per condition were transfected by electroporation with various combinations of $\mathrm{Z}$ and $\mathrm{p} 65$ expression vectors or the appropriate negative control vectors. At $24 \mathrm{~h}$ posttransfection, the cells were scraped from the dishes, washed twice with ice-cold PBS, resuspended in $250 \mu \mathrm{l}$ of $\mathrm{Z} / \mathrm{p} 65$ buffer, and sonicated. The cellular debris was removed by centrifugation, and $100 \mu \mathrm{l}$ of supernatant was reacted with either $15 \mu \mathrm{l}$ of normal rabbit serum or $15 \mu$ l of anti-p65 serum (Santa Cruz Biotechnology; catalog no. SC-109) in a total volume of $500 \mu \mathrm{l}$ of $\mathrm{Z} / \mathrm{p} 65$ buffer. The reactions were rocked for $1 \mathrm{~h}$ at $4^{\circ} \mathrm{C}$ before $20 \mu$ l of preswollen protein A-Sepharose beads (Pharmacia) was added. Samples were again rocked for $1 \mathrm{~h}$ at $4^{\circ} \mathrm{C}$, washed three times with Z/p65 buffer, and boiled in SDSPAGE loading buffer. The proteins were then separated on a $10 \%$ denaturing polyacrylamide gel and transferred to nitrocellulose (Schleicher \& Schuell). Ten microliters of each original cellular extract (directly loaded to demonstrate protein levels prior to immunoprecipitation) were also separated on the denaturing gel and transferred.

Approximately $5 \times 10^{5}$ P3HR 1 cells were equally divided and either induced with $5 \mathrm{mM}$ sodium butyrate plus $30 \mathrm{ng}$ of 12-O-tetradecanoylphorbol-13-acetate (TPA) per ml or left uninduced. After $34 \mathrm{~h}$, the cells were pelleted, washed twice with ice-cold PBS, resuspended in $500 \mu \mathrm{l}$ of Z/p65 buffer, and sonicated. The cellular debris was removed by centrifugation, and supernatant containing $1.9 \mathrm{mg}$ of cellular protein was reacted with either normal rabbit serum ( $3 \mu \mathrm{g}$ of protein) or anti-p65 serum $(3 \mu \mathrm{g})$ (Santa Cruz Biotechnology) in a total volume of $500 \mu \mathrm{l}$ of $\mathrm{Z} / \mathrm{p} 65$ buffer. Hereafter, the immunoprecipitation was performed exactly as for the HeLa cell experiment.
Immunoblotting was performed in PBS with $3 \%$ powdered milk with a 1:10 dilution of monoclonal antibody BZ.1 (a gift of Alan Rickinson) (74) and a 1:2,000 dilution of goat antimouse kappa-chain horseradish peroxidase-conjugated serum (Southern Biotechnology Associates, Inc.; catalog no. 105005), followed by enhanced chemiluminescence performed as recommended by the manufacturer (Amersham Life Sciences). Rabbit anti-p65 serum was used at $1: 2,000$ in $3 \%$ milkPBS, and the secondary antibody was donkey anti-rabbit horseradish peroxidase-conjugated serum (Amersham Life Sciences) at 1:3,000, in the procedure described above for anti-Z immunoblotting.

\section{RESULTS}

The p65 component of NF-кB inhibits the ability of $Z$ to activate EBV early promoters in HeLa cells. In search of a mechanism for the cell type specificity of $\mathrm{Z}$ transactivation function, we first studied the ability of p65 to interfere with Z-induced transactivation of the BHRF1 early promoter of EBV (42). In HeLa cells, the I $\kappa$ B proteins physically bind to

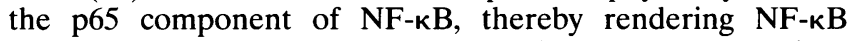
inactive (3). We introduced an expression vector for p65 into HeLa cells to test the ability of transiently overexpressed p65 to inhibit transactivation of the BHRF1 promoter by $\mathrm{Z}$. In the HeLa epithelial cell line, $Z$ by itself efficiently activated the BHRF1 promoter (Fig. 1A). Although p65 alone had little effect on BHRF1 activity, coexpression of p65 with $\mathrm{Z}$ totally inhibited transactivation of BHRF1 by $\mathrm{Z}$. Western blotting (immunoblotting) confirmed that this functional inhibition of $\mathrm{Z}$ is not caused by decreased expression of $\mathrm{Z}$ through inhibition of the $C M V$ promoter driving $Z$ expression in the presence of p65 (see Fig. 8A).

A transforming, alternatively spliced form of p65, called 
p65 , lacks amino acids 222 to 231 of p65 (58). The deletion within the Rel domain of this variant p65 protein is known to interfere with multimerization such that the p65 protein is unable to homodimerize or heterodimerize with NF-кB p50 and only weakly interacts with p65 (58). We examined the effect of this multimerization-defective form of p65 on Z. As shown in Fig. 1A, p65 $\Delta$ had a less profound effect upon the Z-induced transactivation of BHRF1-CAT, suggesting that amino acid residues 222 to 231 (within the Rel homology domain) of p65 are necessary for efficient inhibition of $\mathrm{Z}$ by p65.

We next tested whether transactivation of a second EBV early promoter, BMRF1, by $\mathrm{Z}$ might also be inhibited by p65. Our previous studies have demonstrated that the BMRF1 promoter, which controls the expression of the early antigendiffuse polymerase cofactor (40), responds to $\mathrm{Z}$ in a cell-typespecific manner $(29,32)$. In the lymphoid cell lines Jurkat and Louckes, $\mathrm{Z}$ has very little effect on the BMRF1 promoter; however, in the epithelial cell line HeLa, $\mathrm{Z}$ can efficiently activate BMRF1. Expression of the $\mathrm{Z}$ protein alone produced the expected transactivation of the BMRF1 promoter linked to CAT (Fig. 1B). When a p65 expression vector was introduced along with the $\mathrm{Z}$ expression vector, activation of BMRF1 by $\mathrm{Z}$ was inhibited by $88 \%$. Overexpression of IкB $\alpha$ with $Z$ and p65 resulted in reversal of the p65-induced inhibition of $Z$. Additionally, gel retardation studies indicate that while $\mathrm{Z}$ alone can bind to the BMRF1 promoter (32), p65 alone does not (29a), making it unlikely that p65 is merely competing with $\mathrm{Z}$ for DNA binding sites within this promoter.

Endogenous NF- $\mathrm{KB}$ p65 expression inhibits $Z$ function in the B-cell line Raji. In $B$ cells, I $B$ does not efficiently sequester NF-кB into the cytoplasm, leaving a portion of $\mathrm{NF}-\mathrm{kB}$ free to remain nuclear in localization and functional $(39,63)$. We tested whether overexpression of IкB in the B-cell line Raji might inactivate p65, allowing $\mathrm{Z}$ to function more efficiently. Like other mature B cells, Raji cells are known to contain constitutive NF-кB-binding activity in the nucleus (23). Although expression of $\mathrm{Z}$ alone resulted in some transactivation of BHRF1 in Raji cells (Fig. 1C), overexpression of IкB $\alpha$ increased the ability of $\mathrm{Z}$ to transactivate the BHRF1 promoter fourfold (Fig. 1C, last column). The positive effect of I $\mathrm{B}$ in Raji cells is presumably due to overexpression of I $\mathrm{B} \alpha$ and the sequestration of endogenous p 65 into the cytoplasm, thereby eliminating p65-induced inhibition of $\mathrm{Z}$ function in the nucleus. However, a more indirect effect of IкB $\alpha$ upon $Z$ cannot be ruled out.

$Z$ and p65 physically associate with one another. One possible means by which p65 inhibits $\mathrm{Z}$ is through a direct contact between the proteins. To test whether such an interaction takes place, we performed precipitation experiments using a GST-p65 fusion protein. Full-length $\mathrm{Z}$ protein labeled to very high specific activity with ${ }^{32} \mathrm{P}$ (Fig. $2 \mathrm{~A}$ ) was not precipitated by GSH-agarose beads alone or by beads coated with GST protein (Fig. 2B). However, labeled Z protein was efficiently precipitated by using GST-p65 linked to GSHagarose beads (Fig. 2B).

To begin to determine which portion of $\mathrm{Z}$ is necessary for the contact with the p65 protein, a truncated form of $\mathrm{Z}$ (Flag $\mathrm{Z} \Delta \mathrm{COOH}$ ) in which the carboxy-terminal 74 amino acids of $\mathrm{Z}$ had been deleted was ${ }^{32} \mathrm{P}$ labeled and compared with fulllength $\mathrm{Z}$ for the ability to bind to GST-p65 (Fig. 2C). In contrast to the full-length $\mathrm{Z}$ protein, the carboxy-terminal truncated form of $Z$ was unable to associate with $\mathrm{p} 65$. These last 74 amino acids of $\mathrm{Z}$ contain the basic DNA-binding domain and the coiled-coil dimerization domain.

Because $\mathrm{Z}$ and $\mathrm{p} 65$ are both DNA-binding proteins, the possibility exists that they each nonspecifically interact with contaminating DNA present in bacterial or reticulocyte lysates. This genomic DNA could then serve as a bridge between two DNA-binding proteins, creating the appearance of a proteinprotein interaction (37). Therefore, we treated the lysates containing $\mathrm{Z}$ and p65 with DEAE-Sephacel to remove any DNA present (1). Figure 3B demonstrates that DEAE-Sephacel treatment totally eliminates a tracer probe (to which p65 is known to bind) from all lysates used in Fig. 3A. In these DNA-free lysates, ${ }^{35} \mathrm{~S}$-labeled $\mathrm{Z}$ and $\mathrm{p} 65$ retain the ability to interact with GST-p65 and GST-Z, respectively (Fig. 3A).

The dimerization domain of $Z$ is required for the $Z$-p65 interaction. To ascertain further which domain of $\mathrm{Z}$ is needed for binding directly to $\mathrm{p} 65$, each of a series of truncated $\mathrm{Z}$ proteins was linked to GST (Fig. 2A), and each fusion protein was tested for the ability to precipitate ${ }^{35} \mathrm{~S}$-labeled $\mathrm{p} 65$. The $\mathrm{Z}$ proteins lacking a transactivation domain retained the ability to precipitate p65 (Fig. 2D, GST Z $\Delta 1-79$ and GST Z $\Delta 1-133$ ). However, specific deletion of the dimerization domain was shown to eliminate the Z-p65 interaction. These data suggest that the coiled-coil domain of $\mathrm{Z}$ is required for the interaction with $\mathrm{p} 65$.

To further establish that the dimerization domain of $\mathrm{Z}$ is required for the interaction with p65 and to determine which amino acid residues within the coiled-coil are critical, various mutant forms of the $\mathrm{Z}$ protein were tested for the ability to multimerize with p65 (Fig. 4). These mutant $\mathrm{Z}$ proteins all contain two site-directed mutations within the dimerization domain (mutants are numbered for the amino acids which were mutated, and letters indicate which residues replaced the wild-type amino acids). The abilities of the GST-Z and GSTp65 fusions to complex with the various $Z$ mutants were compared. Mutants Z205R/206D and Z209R/216E as well as wild-type $\mathrm{Z}$ protein all demonstrated the capacity to homodimerize with GST-Z. These same $Z$ proteins interacted efficiently with GST-p65. The remaining $Z$ mutants were found to be incapable of efficient homodimerization (as was previously reported [20]) and also failed to interact with GST-p65.

Mapping the portion of p65 required for the interaction with $\mathbf{Z}$. To similarly determine which part of the p65 protein is needed for contact with $\mathrm{Z}$, we tested the ability of a series of ${ }^{35} S$-labeled mutant and truncated $\mathrm{p} 65$ proteins to interact with the GST-Z fusion protein (Fig. 5A). All of these in vitrotranslated p65 proteins were present in similar amounts (data not shown). None of the $\mathrm{p} 65$ proteins reacted nonspecifically to the GST protein linked to GSH-agarose beads (Fig. 5B). Wild-type p65 and a mutant p65 form, p65 $\Delta$ NLS, both were efficiently precipitated by GST-Z. The p65 $\Delta$ NLS protein, which contains a four-amino-acid substitution within a nuclear localization signal and is incapable of interacting with the IкB $\alpha$ protein (6), still interacted efficiently with Z. Deletion of the last 238 amino acids of p65, which contain the transactivation domain, did not affect the Z-p65 interaction. However, deletion of the region between amino acids 286 through 313 destroyed the ability of $p 65$ to interact with $\mathrm{Z}$. Although the portion of p65 between amino acids 285 and 314 is needed for the binding of p65 to both I $\mathrm{B} \alpha$ and $\mathrm{Z}$, the precise amino acids which are required are not identical, since the p65 $\Delta$ NLS mutant can interact with $\mathrm{Z}$ but not I $\mathrm{KB} \alpha$.

We also tested whether the p65 protein (which lacks 10 amino acids within the Rel homology domain of p65 and was incapable of fully inhibiting transactivation of the BHRF1 promoter by $Z$ ) might be incapable of efficient interaction with GST-Z. As shown in Fig. 6 (lanes 5, 8, and 11), GST-Z efficiently precipitated ${ }^{35} \mathrm{~S}$-labeled, in vitro-translated $\mathrm{Z}$ and p65 proteins. However, although equal amounts of p65 and 


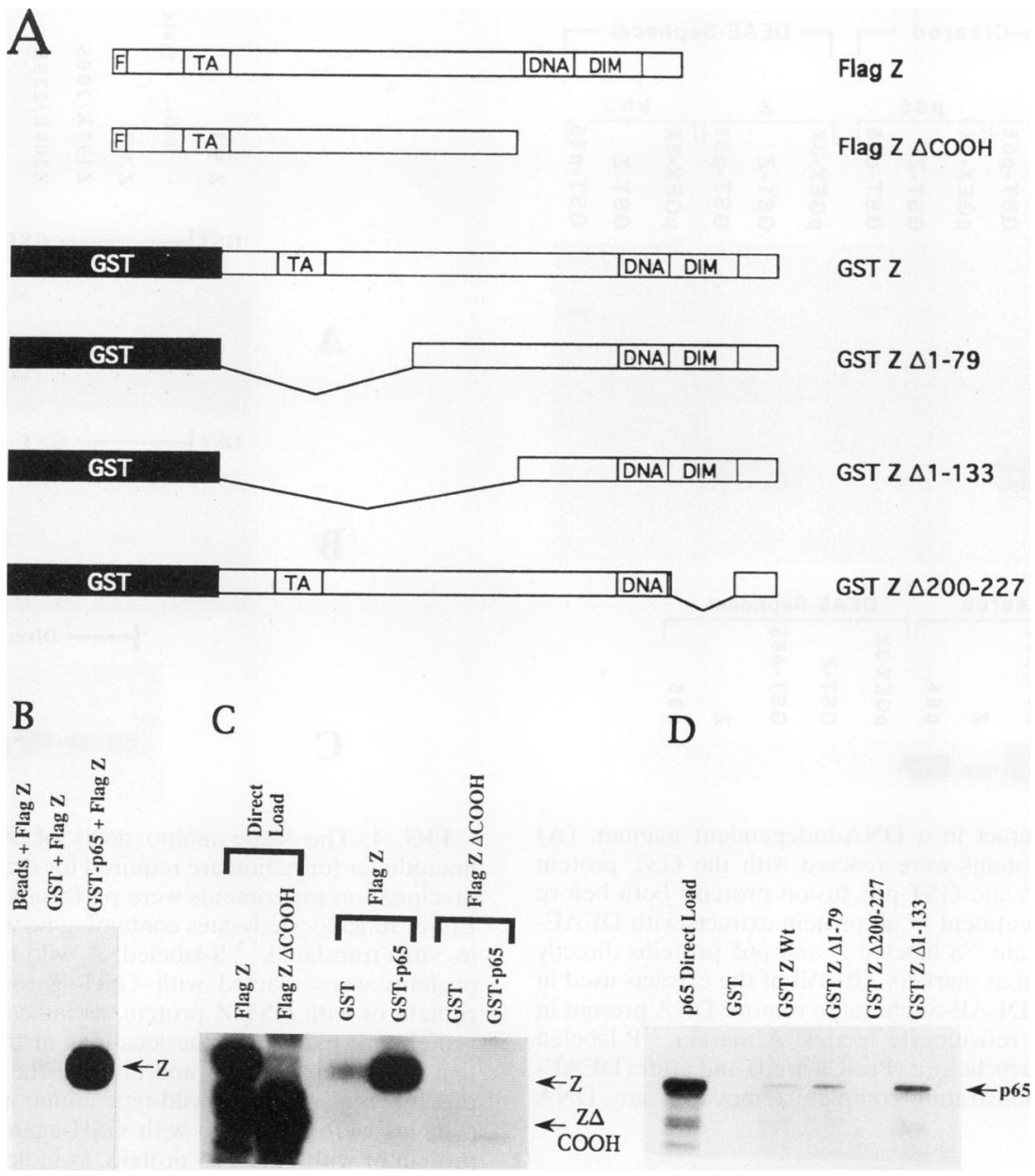

FIG. 2. The direct physical interaction between $\mathrm{Z}$ and $\mathrm{p} 65$ requires the carboxy terminus of $\mathrm{Z}$. (A) Map of the Flag $\mathrm{Z}$ protein containing all 245 amino acids of $Z$ linked to an N-terminal Flag antibody epitope (F) with a kinase site for ${ }^{32} \mathrm{P}$ labeling (8). The transactivation (TA), DNA-binding (DNA), and coiled-coil dimerization (DIM) domains of $Z$ are also shown. The Flag $\mathrm{Z} \Delta \mathrm{COOH}$ protein lacks the last 74 amino acids of Flag Z. A map of GST Z which contains the GST protein from pGEX-3X (Pharmacia) linked to the wild-type full-length Z protein is shown along with various truncated $Z$ proteins which have also been linked to GST. The truncated $Z$ proteins are named by the amino acid residues which have been removed. (B) The GST protein or the GST-p65 fusion protein was linked to GSH-agarose beads, and these beads were incubated with Flag $\mathrm{Z}$ protein which had been labeled with ${ }^{32} \mathrm{P}$ to a high specific activity. Precipitated bead-protein complexes were washed five times and loaded on an SDS-polyacrylamide gel. (C) To map the portion of Z necessary for the Z-p65 interaction, a truncated form of Z was also tested in GST precipitation experiments performed as described for panel $\mathrm{B}$. The first two lanes show 5,000 cpm of ${ }^{32} \mathrm{P}$-labeled Flag Z and Flag Z $\triangle \mathrm{COOH}$ loaded directly on the SDS-polyacrylamide gel. Flag Z was reacted with GSH-agarose beads coated with GST protein or with GST-p65 protein, as indicated. On the same gel, Flag Z $\mathrm{CCOOH}$ was reacted with GSH-agarose beads coated with GST protein, or with GST-p65 protein, as indicated. (D) To determine which domains of the $Z$ protein are necessary for the Z-p65 physical interaction, GST fusion proteins containing various truncated forms of the $\mathrm{Z}$ protein were linked to GSH-agarose beads and incubated with in vitro-translated, ${ }^{35} \mathrm{~S}$-labeled p65 protein. The carboxy-terminal 112 amino acids (GST Z $\Delta 1-133$ ) were sufficient for the interaction with p65, yet the truncated $Z$ protein lacking the coiled-coil dimerization domain failed to precipitate p65. The GST-Z fusion proteins were present on the beads in similar amounts (data not shown). The p65 protein retained by GST-Z appeared lighter than the previous experiments because of the use of ${ }^{35}$ S-labeled protein (versus ${ }^{32} \mathrm{P}-$-labeled $\mathrm{Z}$ protein in panels $\mathrm{B}$ and $\mathrm{C}$ ).

p65 $\Delta$ protein were used (Fig. 6, lanes 2 and 3), significantly more p65 than p65 protein bound to $\mathrm{Z}$ (Fig. 6 , lanes 8 and 11). This result provides further evidence that the Rel homology domain of p65 is required for the interaction with $Z$.

$Z$ and $p 65$ can be coimmunoprecipitated in vitro and in vivo. We used coimmunoprecipitation as a second method to confirm the physical interaction between $\mathrm{Z}$ and p65. In the first set of experiments, the source of p65 protein was the GST-p65 fusion protein and the source of $Z$ was ${ }^{32} \mathrm{P}$-labeled Flag $Z$ (Fig. 2A). Rabbit anti-p65 serum, as expected, could specifically precipitate ${ }^{35} \mathrm{~S}$-labeled $\mathrm{p} 65$, whereas the preimmune rabbit serum did not (Fig. 7, last two lanes). Preimmune serum did not precipitate $\mathrm{Z}$ in the presence of GST-p65 or the negative control GST protein alone. Anti-p65 serum could not precipitate $Z$ in the absence of p65, but when GST-p65 was added with ${ }^{32} \mathrm{P}$-labeled $\mathrm{Z}$, the $\mathrm{Z}$ was coprecipitated.

We also performed coimmunoprecipitations to confirm that an interaction between $\mathrm{Z}$ and p65 occurs in vivo, using HeLa cells transfected exactly as those used for Fig. 1. Rabbit anti-p65 serum added to extracts from HeLa cells which had been transfected with expression vectors for $Z$ and for p65 coprecipitated $Z$ protein (Fig. 8A, lower panel, lane 4). Even in the absence of transfected $p 65$, the $Z$ protein produced from the transfected $\mathrm{Z}$ expression vector was precipitated through 


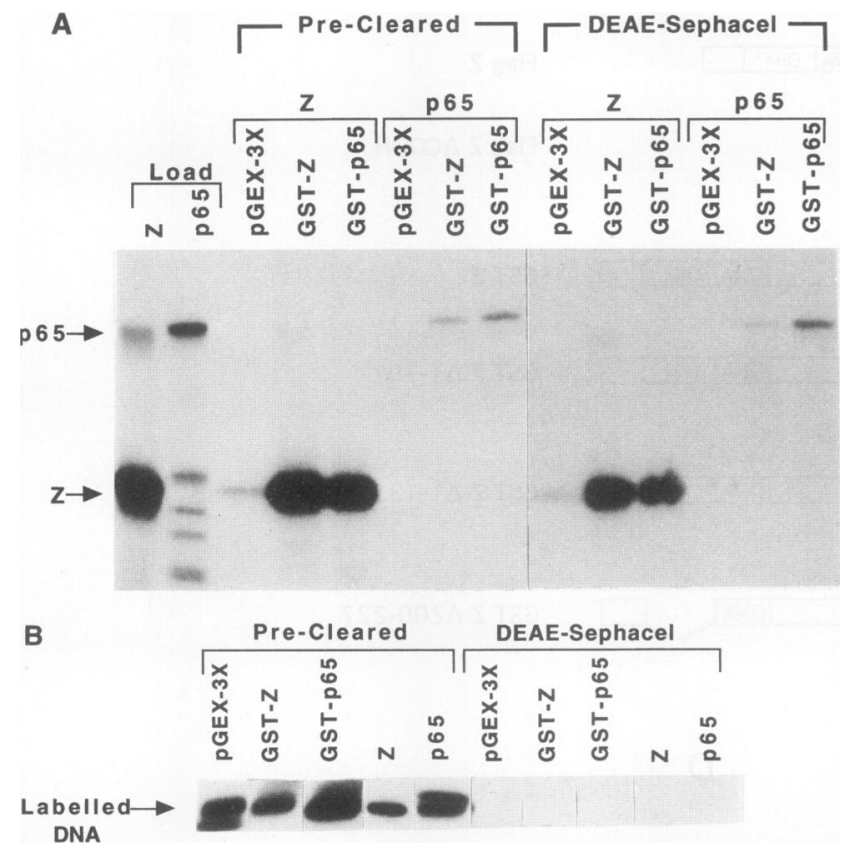

FIG. 3. Z and p65 interact in a DNA-independent manner. (A) ${ }^{35} \mathrm{~S}$-labeled $\mathrm{Z}$ and $\mathrm{p} 65$ proteins were reacted with the GST protein (pGEX-3X) or the GST-Z and GST-p65 fusion proteins both before (Pre-Cleared) and after treatment of all protein extracts with DEAESephacel. Load lanes contain ${ }^{35} \mathrm{~S}$-labeled $\mathrm{Z}$ and p65 proteins directly loaded onto the protein gel as markers. (B) All of the extracts used in panel A were treated with DEAE-Sephacel to remove DNA present in the bacterial extracts and reticulocyte lysates. A marker ${ }^{32} \mathrm{P}$-labeled probe is shown for all extracts before (Pre-Cleared) and after (DEAESephacel) treatment, demonstrating complete removal of any DNA present in the extracts.

its interaction with endogenous p65 protein (Fig. 8A, lower panel, lane 2 ). $Z$ protein was not nonspecifically precipitated by normal rabbit serum. These data imply that the direct physical interaction between $\mathrm{Z}$ and p65 may mediate the functional inhibition of $\mathrm{Z}$ transactivation by $\mathrm{p} 65$.

Even stronger evidence that an interaction between $Z$ and p65 occurs in vivo was demonstrated by using the endogenous, virally produced $\mathrm{Z}$ protein from the EBV-positive cell line P3HR1. These cells were treated with sodium butyrate and TPA to induce the expression of $Z$ protein. Anti-p65 serum coimmunoprecipitated endogenous $\mathrm{p} 65$ and $\mathrm{Z}$ protein from induced cells but not from latently infected, uninduced P3HR1 cells which do not express $\mathrm{Z}$ protein (Fig. 8B). Thus, the $\mathrm{Z}$ and p65 proteins appear to associate through a direct physical interaction both in vitro and in vivo.

\section{DISCUSSION}

In this report, we have demonstrated that the EBV $\mathrm{Z}$ protein, which triggers the switch from latent to lytic infection, can interact directly with the p65 component of NF-кB. This interaction is mediated through the coiled-coil dimerization domain of $Z$ and the Rel homology domain of p65. We demonstrate that $\mathrm{p} 65$ inhibits the ability of $\mathrm{Z}$ to transactivate early EBV promoters. Therefore, B-cell-specific nuclear expression of NF- $\mathrm{KB}$ or other Rel proteins may be one mechanism of promoting EBV latency in B cells.

Heteromultimerization not only within families of transactivators but also between whole classes of transactivators

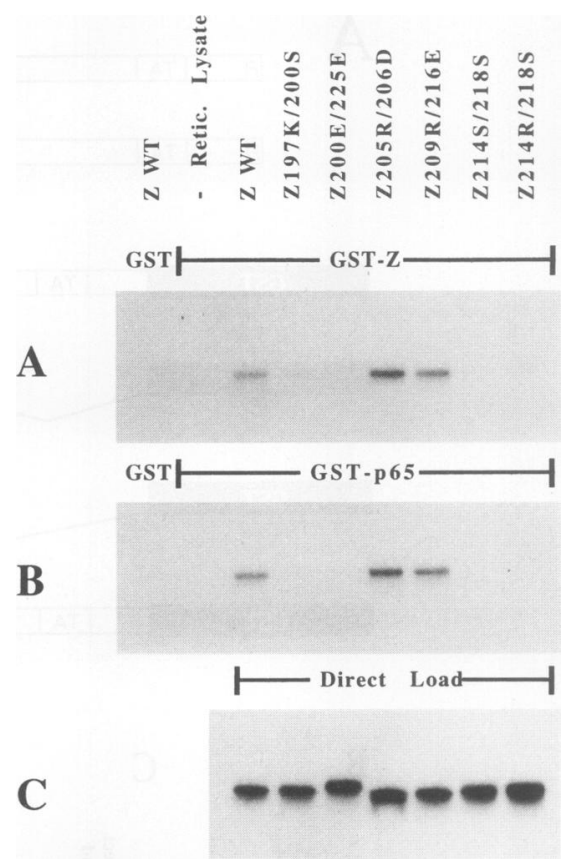

FIG. 4. The same amino acids of $\mathrm{Z}$ which are important for homodimer formation are required for the Z-p65 interaction. (A) GST precipitation experiments were performed similarly to those in Fig. 2. Either reticulocyte lysates containing no Z RNA ( - Retic. Lysate) or in vitro-translated, ${ }^{35} \mathrm{~S}$-labeled $\mathrm{Z}$ wild-type $(\mathrm{Z}$ WT) or $\mathrm{Z}$ mutant proteins were reacted with GSH-agarose beads coated with GST protein or with GST-Z protein, as indicated. Mutant forms of the Z protein are named for the locations of the amino acid residues of $Z$ that have been mutated and indicate the amino acids which now are present in place of the wild-type amino acids. (B) The ${ }^{35} \mathrm{~S}$-labeled $\mathrm{Z}$ proteins were incubated with GSH-agarose beads coated with GST protein or with GST-p65 protein, as indicated. (C) The various forms of ${ }^{35} \mathrm{~S}$-labeled $\mathrm{Z}$ proteins were loaded directly on an SDS-polyacrylamide gel to demonstrate that similar counts per minute of protein were used in all of the conditions in panels A and B.

increases the complexity in regulation of gene expression. Recently, members of the bZIP family have been shown to directly interact with a number of diverse proteins, including helix-loop-helix-containing transcription factors $(7,8)$, steroid receptors (61), and the TATA-binding protein (41). Of particular relevance to the Z-p65 interaction described here are the recent reports showing that another bZIP protein (NF-IL6) can interact directly with both NF-кB p50 (38) and p65 (67). Interestingly, as is the case with the Z-p65 interaction, the p65-NF-IL6 interaction requires the Rel domain of p65 and the leucine zipper of NF-IL6 (67).

The leucine zipper domain of $\mathrm{Z}$ and the Rel domain of $\mathrm{p} 65$ are responsible for homodimerization of the respective proteins $(10,20,35,52,58)$ but also appear to be important mediators of interactions with other proteins. We found that the $\mathrm{Z}$ mutants which disrupt homodimerization by interfering with the hydrophobic face of the $\mathrm{Z}$ coiled-coil domain (20) are also unable to interact with p65 (Fig. 4). It is possible that the hydrophobic face of the zipper which normally contacts a second $\mathrm{Z}$ monomer contacts p65 instead, thereby excluding $\mathrm{Z}$ from forming a functional binding protein or perhaps changing the specificity of DNA binding by Z. Alternatively, it is possible that while the $\mathrm{Z}$ homodimerization domain is necessary for the $\mathrm{Z}$-p65 interaction, the interaction between $\mathrm{Z}$ and $\mathrm{p} 65$ is 


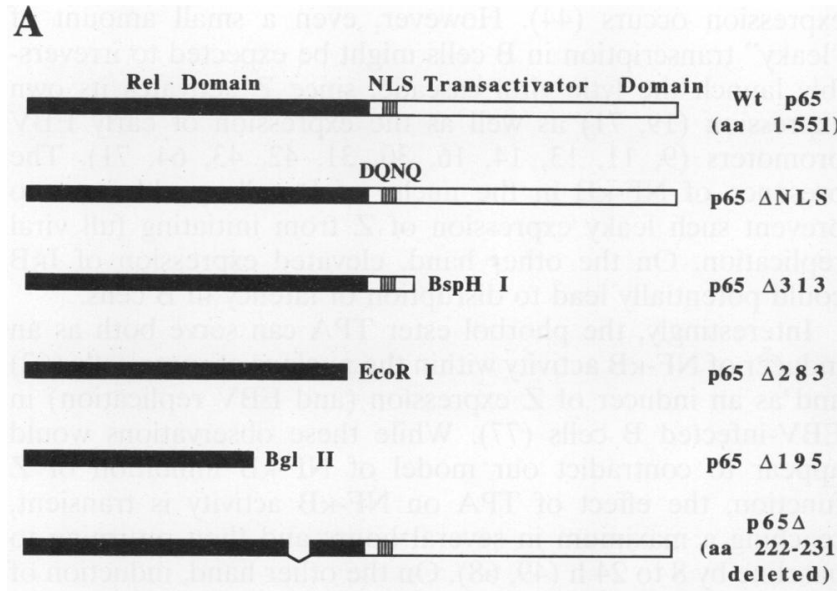

B

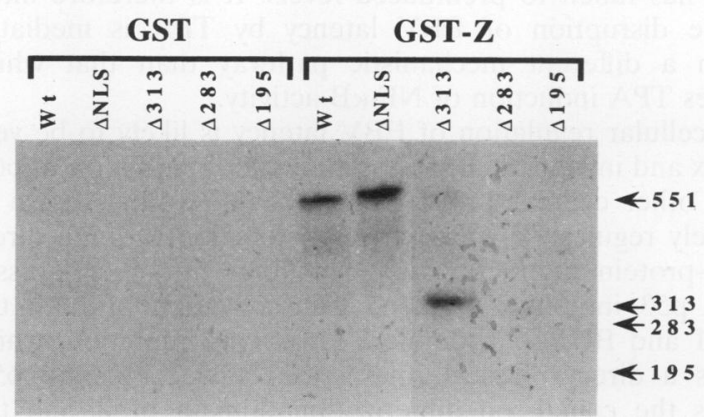

FIG. 5. Mapping the region of the p65 protein necessary for the interaction with Z. (A) Maps of wild-type (WT), mutant, and deletional forms of the p65 protein (translated in vitro and ${ }^{35} \mathrm{~S}$ labeled). To generate the p65 $\triangle$ NLS protein, a four-amino-acid mutation from KRKR to DQNQ was introduced in the nuclear localization signal of p65. Carboxy-terminal deletion proteins were named by using the number corresponding to the terminal amino acid residue. (B) The panel of p65 proteins was reacted with GSH-agarose beads coated with GST protein or with GST-Z (wild-type) protein, as indicated. Each p65 protein was expressed in vitro at the same level, and the arrows show where loaded aliquots of the indicated proteins ran on the gel.

mediated through another, yet unmapped portion of the $\mathrm{Z}$ protein.

As is the case for the p65 interaction with NF-IL6, the Rel portion of p65 was also found to be essential for interaction with $\mathrm{Z}$. The $\mathrm{p} 65$ protein has been noted to contain a putative leucine zipper, the disruption of which interferes with the function of the p65 activation domain (58). Although this motif theoretically might dimerize with $\mathrm{Z}$, the leucine zipper is located in the carboxy-terminal portion of p65 which is dispensable for binding to $\mathrm{Z}$. Additionally, the p $65 \Delta$ protein (which lacks amino acids 222 to 231 of p65) contains an intact leucine zipper, yet $\mathrm{p} 65 \Delta$ interacts less efficiently with $\mathrm{Z}$ than does full-length $\mathrm{p} 65$ protein.

Interactions of viral proteins with NF- $\mathrm{BB}$ are not without precedent; however, the physical binding of $\mathrm{Z}$ to $\mathrm{p} 65$ is a novel

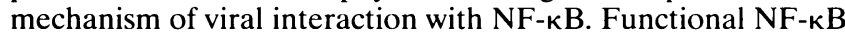
binding sites are found in the regulatory regions controlling the expression of important proteins encoded by several viruses $(12,46,47,55,60)$. The Tax protein of human T-cell leukemia virus type I can interact directly with the p105 precursor of

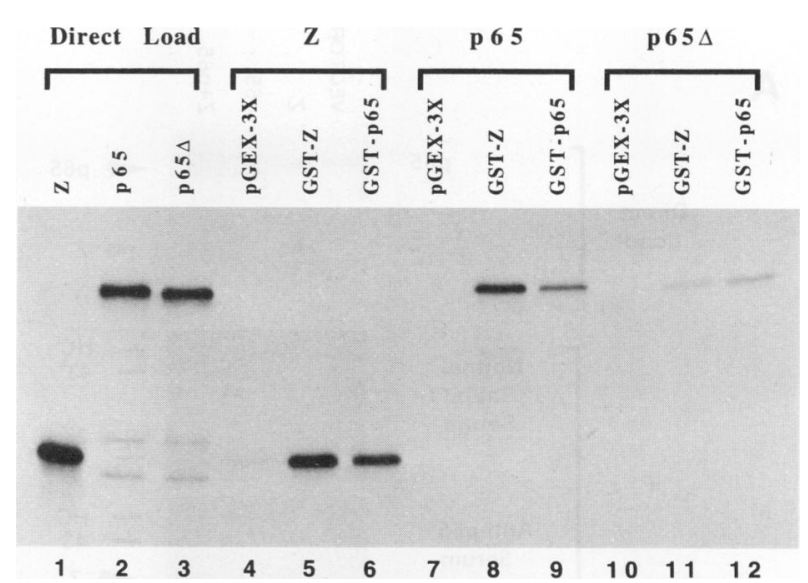

FIG. 6. The same portion of p65 which is important for multimerization is required for efficient protein-protein interaction with $\mathrm{Z}$. In vitro-translated, ${ }^{35} \mathrm{~S}$-labeled wild-type $\mathrm{Z}$, wild-type $\mathrm{p} 65$, and $\mathrm{p} 65 \Delta$ (the last protein in Fig. 5A) were directly loaded in lanes 1 to 3 at $1 / 25$ the amount used in GST precipitation conditions shown in lanes 4 to 12 . GSH-agarose beads coated with the GST, GST-Z, or GST-p65 proteins were reacted with ${ }^{35} \mathrm{~S}$-labeled $Z$ (lanes 4 to 6), p65 (lanes 7 to 9), or p $65 \Delta$ (lanes 10 to 12 ). The p65s protein, which multimerizes poorly with native p65 (illustrated by the fold decrease from lane 9 to lane 12) interacts even less with $\mathrm{Z}$ (note the fold decrease from lane 8 to lane $11)$.

NF-кB p50 (28). The human immunodeficiency virus type 1 protease processes the p105 precursor to a functional p50 product (54). Numerous viruses exhibit the capacity to transactivate promoters through NF- $\mathrm{KB}$ sites (reviewed in reference 2). Interestingly, the EBV LMP1 protein, which is expressed in latently infected B cells, also activates both the human immunodeficiency virus long terminal repeat (25) and the cellular A20 zinc finger protein (36) through NF- $\mathrm{KB}$ sites. The induction of NF- $\mathrm{KB}$ activity by LMP1 could potentially strengthen the latent state by inhibiting $\mathrm{Z}$ protein function.

In contrast to the positive effect that NF-KB has on viral replication in the preceding examples, EBV appears to use

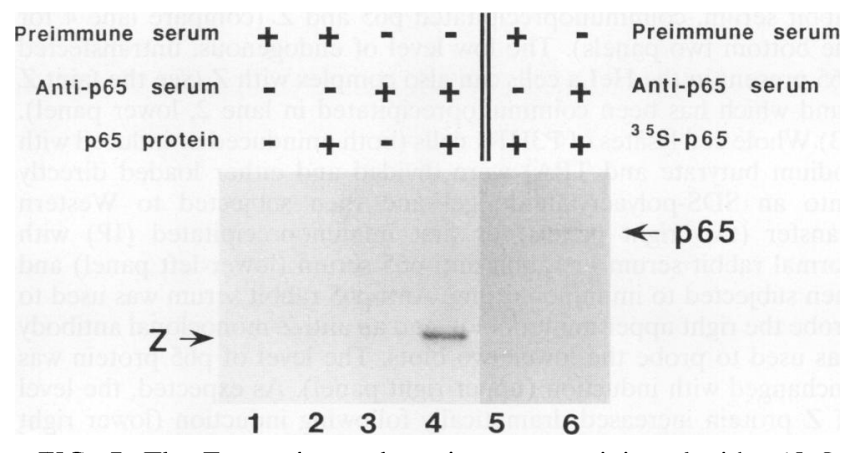

FIG. 7. The $\mathrm{Z}$ protein can be coimmunoprecipitated with $\mathrm{p} 65$. In vitro, bacterially expressed GST-p65 protein (or GST protein alone as a negative control) was reacted with ${ }^{32} \mathrm{P}$-labeled Flag $\mathrm{Z}$ protein (Fig. $2 \mathrm{~A})$ and then incubated with rabbit preimmune serum or rabbit anti-p65 serum, as shown in the conditions specified above lanes 1 to 4. The ${ }^{32} \mathrm{P}$-labeled $\mathrm{Z}$ protein was added in equal amounts to all of the reactions shown in lanes 1 to 4 ; however, $Z$ was precipitated only in the presence of p65 protein and anti-p65 antibody (lane 4). Equal counts of in vitro-translated, ${ }^{35} \mathrm{~S}$-labeled $\mathrm{p} 65$ protein were added to lanes 5 and 6 to demonstrate that the anti-p65, but not the preimmune serum, can immunoprecipitate $\mathrm{p} 65$ protein. 


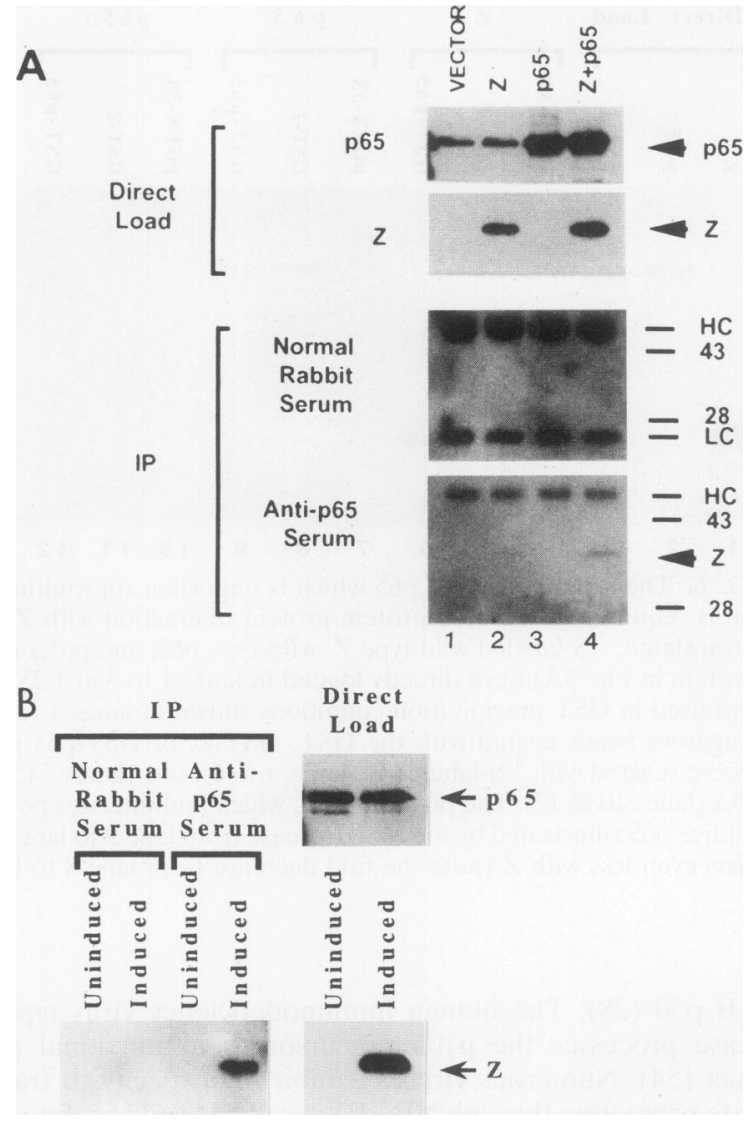

FIG. 8. The $\mathrm{Z}$ and $\mathrm{p} 65$ proteins form a complex in vivo. (A) HeLa cells were transfected with $3 \mu \mathrm{g}$ each of pHD1013 plus pCMV-4T (lane 1), CMV-Z plus pCMV-4T (lane 2), pCMV-p65 plus pHD1013 (lane 3 ), or pCMV-p65 plus CMV-Z (lane 4). Whole cell lysates of the transfected HeLa cells were divided and either loaded directly onto an SDS-polyacrylamide gel and then subjected to Western transfer (upper two panels) or first immunoprecipitated with normal rabbit serum (third panel) or rabbit anti-p65 serum (fourth panel) and then subjected to immunoblotting. Anti-p65 rabbit serum was used to probe the first immunoblot, and an anti- $Z$ monoclonal antibody was used to probe the last three blots. The anti-p65 serum, but not the normal rabbit serum, coimmunoprecipitated $\mathrm{p} 65$ and $\mathrm{Z}$ (compare lane 4 for the bottom two panels). The low level of endogenous, untransfected p65 present in the HeLa cells can also complex with $\mathrm{Z}$ (see the faint $\mathrm{Z}$ band which has been coimmunoprecipitated in lane 2, lower panel). (B) Whole cell lysates of P3HR1 cells (both uninduced or induced with sodium butyrate and TPA) were divided and either loaded directly onto an SDS-polyacrylamide gel and then subjected to Western transfer (two right panels) or first immunoprecipitated (IP) with normal rabbit serum or rabbit anti-p65 serum (lower left panel) and then subjected to immunoblotting. Anti-p65 rabbit serum was used to probe the right upper immunoblot, and an anti- $\mathrm{Z}$ monoclonal antibody was used to probe the lower two blots. The level of p65 protein was unchanged with induction (upper right panel). As expected, the level of $\mathrm{Z}$ protein increased dramatically following induction (lower right panel). Anti-p65 serum (not normal rabbit serum) coimmunoprecipitated $Z$ from the induced, but not from the uninduced, P3HR1 cell extracts.

NF-кB as an inhibitor of productive infection. Infection of humans by EBV primarily involves epithelial cells and $B$ cells (33). In epithelial cells, the virus replicates efficiently, producing virions which are shed into the saliva (66). In B cells, EBV exists primarily in a latent state in which little if any $Z$ gene expression occurs (44). However, even a small amount of "leaky" transcription in B cells might be expected to irreversibly launch the lytic viral cascade, since $\mathrm{Z}$ activates its own expression $(19,71)$ as well as the expression of early EBV promoters $(9,11,13,14,16,30,31,42,43,64,71)$. The presence of NF- $\mathrm{KB}$ in the nuclei of $\mathrm{B}$ cells could serve to prevent such leaky expression of $\mathrm{Z}$ from initiating full viral replication. On the other hand, elevated expression of IкB could potentially lead to disruption of latency in B cells.

Interestingly, the phorbol ester TPA can serve both as an inducer of NF- $\kappa B$ activity within the nucleus of some cells (62) and as an inducer of $\mathrm{Z}$ expression (and EBV replication) in EBV-infected B cells (77). While these observations would appear to contradict our model of NF-кB inhibition of $Z$ function, the effect of TPA on NF- $\mathrm{B}$ activity is transient, reaching a maximum in several hours and then returning to baseline by 8 to $24 \mathrm{~h}(49,68)$. On the other hand, induction of EBV productive infection by TPA is very slow, with an onset following 2 to 3 days of exposure and reaching a maximum in 5 to 8 days (77). Hence, EBV is induced by TPA after NF-кB activity has fallen to preinduced levels. It is therefore likely that the disruption of EBV latency by TPA is mediated through a different mechanistic pathway than that which mediates TPA induction of NF- $\mathrm{kB}$ activity.

The cellular regulation of EBV latency is likely to be very complex and involve multiple mechanisms. In addition to p65, several other cellular proteins have been recently shown to negatively regulate $Z$ transactivation function through direct protein-protein interactions. The cellular tumor suppressor protein $\mathrm{p} 53$ inhibits Z-induced transactivation of both the BMRF1 and BHRF1 promoters (76). This inhibition, which involves a direct physical interaction between $\mathrm{Z}$ and $\mathrm{p} 53$, requires the coiled-coil dimerization domain of $\mathrm{Z}$ and the carboxy-terminal portion of p53 (76). In a similar manner, the retinoic acid receptors, $\mathrm{RAR} \alpha$ and $\mathrm{RXR} \alpha$, repress the ability of $\mathrm{Z}$ to transactivate the BMRF1 promoter and can physically associate with the $Z$ protein (65). In addition to negative control of $\mathrm{Z}$ transactivation function, control of BZLF1 transcription in different cell types must play a role in determining whether EBV remains latent versus productive. In this regard, we have recently shown that the BRLF1 promoter (one of two EBV promoters driving $\mathrm{Z}$ expression) is constitutively active in epithelial cells but inactive in B cells (75).

Although a number of cellular factors have been shown to inhibit $\mathrm{Z}$ transactivation function, in certain circumstances disruption of viral latency can occur, and therefore mechanisms whereby these negative regulators of $Z$ function can be circumvented must also exist. Clearly, if $\mathrm{Z}$ transcription is induced to a sufficient level, then $\mathrm{Z}$ can further activate its own transcription and thereby produce enough protein to overcome the effect of negative cellular regulators. $Z$ transactivator function in certain lymphocytic cell lines is increased by the EBV BRLF1 immediate-early gene product (29) or the c-myb oncogene product (32). In addition, the interactions between $Z$ and cellular proteins may well be influenced by $Z$ phosphorylation, since there is recent evidence that $\mathrm{Z}$ is phosphorylated in vivo and that dephosphorylation of $\mathrm{Z}$ is associated with the disruption of viral latency (17). In any event, it is now clear that the regulation of EBV latency is cell type specific and involves interactions with numerous viral and cellular proteins.

\section{ACKNOWLEDGMENTS}

This work was supported by Public Health Service grants P01CA19014, K04-CA01711, and F32-AI08408 from the National Institutes of Health and grant MV-532 from the American Cancer Society. 
We thank Amer Beg, Alain Sergeant, Craig Rosen, Paul Farrell, Erik Flemington, and Samuel Speck for gifts of plasmids and Alan Rickinson for monoclonal antibody BZ.1.

\section{REFERENCES}

1. Artandi, S., and K. Calame. 1993. Glutathione $S$-transferase fusion protein affinity chromatography to assess biochemical interactions between DNA-binding proteins, p. 267-279. In K. W. Adolph (ed.), Methods in molecular genetics. Academic Press, Inc., San Diego, Calif.

2. Baeuerle, P. A. 1991. The inducible transcription activator NFkappa B: regulation by distinct protein subunits. Biochim. Biophys. Acta 1072:63-80.

3. Baeuerle, P. A., and D. Baltimore. 1988. IкB: a specific inhibitor of the NF-kB transcription factor. Science 242:540-546.

4. Baeuerle, P. A., and D. Baltimore. 1989. A 65-kD subunit of active

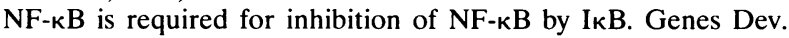
3:1689-1689-1698.

5. Baldwin, A. S., and P. A. Sharp. 1988. Two transcription factors, NF- $\mathrm{KB}$ and $\mathrm{H} 2 \mathrm{TF} 1$, interact with a single regulatory sequence in the class I major histocompatibility complex promoter. Proc. Natl. Acad. Sci. USA 85:723-727.

6. Beg, A. A., S. M. Ruben, R. I. Scheinman, S. Haskill, C. A. Rosen, and A. S. Baldwin. 1992. IKB interacts with the nuclear localization sequences of the subunits of NF-kB: a mechanism for cytoplasmic retention. Genes Dev. 6:1899-1913.

7. Bengal, E., L. Ransone, R. Scharfmann, V. J. Dwarki, S. J. Tapscott, H. Weintraub, and I. M. Verma. 1992. Functional antagonism between c-jun and MyoD proteins: a direct physical association. Cell 68:507-519.

8. Blanar, M. A., and W. J. Rutter. 1992. Interaction cloning: identification of a helix-loop-helix zipper protein that interacts with c-fos. Science 256:1014-1018.

9. Buisson, M., E. Manet, M. Trescol-Biemont, H. Gruffat, B. Durand, and A. Sergeant. 1989. The Epstein-Barr virus (EBV) early protein EB2 is a posttranscriptional activator expressed under the control of EBV transcription factors EB1 and R. J. Virol. 63:5276-5284.

10. Chang, Y. N., D. L. Dong, G. S. Hayward, and S. D. Hayward. 1990. The Epstein-Barr virus Zta transactivator: a member of the bZIP family with unique DNA-binding specificity and a dimerization domain that lacks the characteristic heptad leucine zipper motif. J. Virol. 64:3358-3369.

11. Chavrier, P., H. Gruffat, A. Chevallier-Greco, M. Buisson, and A. Sergeant. 1989. The Epstein-Barr virus (EBV) early promoter DR contains a cis-acting element responsive to the EBV transactivator EB1 and an enhancer with constitutive and inducible activities. J. Virol. 63:607-614.

12. Cherrington, J. M., and E. S. Mocarski. 1989. Human cytomegalovirus ie1 transactivates the $\alpha$ promoter-enhancer via an 18-basepair repeat element. J. Virol. 63:1435-1440.

13. Chevallier-Greco, A., H. Gruffat, E. Manet, A. Calender, and A. Sergeant. 1989. The Epstein-Barr virus (EBV) DR enhancer contains two functionally different domains: domain $\mathrm{A}$ is constitutive and cell specific, domain B is transactivated by the EBV early protein R. J. Virol. 63:615-623.

14. Chevallier-Greco, A., E. Manet, P. Chavrier, C. Mosnier, J. Daillie, and A. Sergeant. 1986. Both Epstein-Barr virus (EBV)encoded trans-acting factors, EB1 and EB2, are required to activate transcription from an EBV early promoter. EMBO J. 5:3243-3249.

15. Countryman, J., and G. Miller. 1985. Activation of expression of latent Epstein-Barr herpesvirus after gene transfer with a small cloned subfragment of heterogeneous viral DNA. Proc. Natl. Acad. Sci. USA 82:4085-4089.

16. Cox, M. A., J. Leahy, and J. M. Hardwick. 1990. An enhancer within the divergent promoter of Epstein-Barr virus responds synergistically to the $\mathrm{R}$ and $\mathrm{Z}$ transactivators. J. Virol. 64:313-321.

17. Daibata, M., R. E. Humphreys, and T. Sairenji. 1992. Phosphorylation of the Epstein-Barr virus BZLF1 immediate-early gene product ZEBRA. Virology 188:916-920.

18. Farrell, P. J., D. T. Rowe, C. M. Rooney, and T. Kouzarides. 1989. Epstein-Barr virus BZLF1 trans-activator specifically binds to a consensus AP-1 site and is related to c-fos. EMBO J. 8:127-132.

19. Flemington, E., and S. H. Speck. 1990. Autoregulation of EpsteinBarr virus putative lytic switch gene BZLF1. J. Virol. 64:12271232.

20. Flemington, E., and S. H. Speck. 1990. Evidence for coiled-coil dimer formation by an Epstein-Barr virus transactivator that lacks a heptad repeat of leucine residues. Proc. Natl. Acad. Sci. USA 87:9459-9463.

21. Ghosh, S., A. M. Gifford, L. R. Riviere, P. Tempst, G. P. Nolan, and D. Baltimore. 1990. Cloning of the p50 DNA binding subunit of NF-kB: homology to rel and dorsal. Cell 62:1019-1029.

22. Giot, J. F., I. Mikaelian, M. Buisson, E. Manet, I. Joab, J. C. Nicolas, and A. Sergeant. 1991. Transcriptional interference between the EBV transcription factors EB1 and R: both DNAbinding and activation domains of EB1 are required. Nucleic Acids Res. 19:1251-1258.

23. Goldfeld, A. E., J. L. Strominger, and C. Doyle. 1991. Human tumor necrosis factor $\alpha$ gene regulation in phorbol ester stimulated $\mathrm{T}$ and $\mathrm{B}$ cell lines. J. Exp. Med. 174:73-81.

24. Gorman, C. M., L. F. Moffat, and B. H. Howard. 1982. Recombinant genomes which express chloramphenicol acetyltransferase in mammalian cells. Mol. Cell. Biol. 2:1044-1051.

25. Hammarskjold, M. L., and M. C. Simurda. 1992. Epstein-Barr virus latent membrane protein transactivates the human immunodeficiency virus type 1 long terminal repeat through induction of NF-кB activity. J. Virol. 66:6496-6501.

26. Hardwick, J. M., P. M. Lieberman, and S. D. Hayward. 1988. A new Epstein-Barr virus transactivator, $R$, induces expression of a cytoplasmic early antigen. J. Virol. 62:2274-2284.

27. Haskill, S., A. A. Beg, S. M. Tompkins, J. S. Morris, A. D. Yurochko, J. A. Sampson, K. Mondal, P. Ralph, and A. S. Baldwin. 1991. Characterization of an immediate-early gene induced in adherent monocytes that encodes IкB-like activity. Cell 65:1281-1289.

28. Hirai, H., J. Fujisawa, T. Suzuki, K. Ueda, M. Muramatsu, A. Tsuboi, N. Arai, and M. Yoshida. 1992. Transcriptional activator Tax of HTLV-1 binds to the NF-kB precursor p105. Oncogene 7:1737-1742.

29. Holley-Guthrie, E. A., E. B. Quinlivan, E. C. Mar, and S. Kenney. 1990. The Epstein-Barr virus (EBV) BMRF1 promoter for early antigen (EA-D) is regulated by the EBV transactivators, BRLF1 and BZLF1, in a cell-specific manner. J. Virol. 64:3753-3759.

29a.Kenney, S. Unpublished data.

30. Kenney, S., E. Holley-Guthrie, E. C. Mar, and M. Smith. 1989. The Epstein-Barr virus BMLF1 promoter contains an enhancer element that is responsive to the BZLF1 and BRLF1 transactivators. J. Virol. 63:3878-3883.

31. Kenney, S., J. Kamine, E. Holley-Guthrie, E. C. Mar, J. C. Lin, D. Markovitz, and J. Pagano. 1989. The Epstein-Barr virus immediate-early gene product, BMLF1, acts in trans by a posttranscriptional mechanism which is reporter gene dependent. J. Virol. 63:3870-3877.

32. Kenney, S. C., E. Holley-Guthrie, E. B. Quinlivan, D. Gutsch, Q. Zhang, T. Bender, J. F. Giot, and A. Sergeant. 1992. The cellular oncogene c-myb can interact synergistically with the Epstein-Barr virus BZLF1 transactivator in lymphoid cells. Mol. Cell. Biol. 12:136-146.

33. Kieff, E., and D. Leibowitz. 1990. Epstein-Barr virus and its replication, p. 1889-1920. In B. N. Fields, D. M. Knipe, R. M. Chanock, M. S. Hirsch, J. L. Melnick, T. P. Monath, and B. Roizman (ed.), Virology. Raven Press, New York.

34. Kieran, M., V. Blank, F. Logeat, J. Vandekerckhove, F. Lottspeich, B. O. Le, M. B. Urban, P. Kourilsky, P. A. Baeuerle, and A. Israel. 1990. The DNA binding subunit of NF- $\mathrm{B}$ B is identical to factor KBF1 and homologous to the rel oncogene product. Cell 62:10071018.

35. Kouzarides, T., G. Packham, A. Cook, and P. J. Farrell. 1991. The BZLF1 protein of EBV has a coiled coil dimerisation domain without a heptad leucine repeat but with homology to the C/EBP leucine zipper. Oncogene 6:195-204.

36. Laherty, C. D., H. M. Hu, A. W. Opipari, F. Wang, and V. M. Dixit. 1992. The Epstein-Barr virus LMP1 gene product induces A20 zinc finger protein expression by activating nuclear factor $\kappa B$. J. 
Biol. Chem. 267:24157-24160.

37. Lai, J. S., and W. Herr. 1992. Ethidium bromide provides a simple tool for identifying genuine DNA-independent protein associations. Proc. Natl. Acad. Sci. USA 89:6958-6962.

38. LeClair, K. P., M. A. Blanar, and P. A. Sharp. 1992. The p50 subunit of NF-кB associates with the NF-IL6 transcription factor. Proc. Natl. Acad. Sci. USA 89:8145-8149.

39. Lenardo, M. J., and D. Baltimore. 1989. NF-кB: a pleiotropic mediator of inducible and tissue-specific gene control. Cell 58: 227-229.

40. Li, J. S., B. S. Zhou, G. E. Dutschman, S. P. Grill, R. S. Tan, and Y. C. Cheng. 1987. Association of Epstein-Barr virus early antigen diffuse component and virus-specified DNA polymerase activity. J. Virol. 61:2947-2949.

41. Lieberman, P. M., and A. J. Berk. 1991. The Zta trans-activator protein stabilizes TFIID association with promoter DNA by direct protein-protein interaction. Genes Dev. 5:2441-2454.

42. Lieberman, P. M., J. M. Hardwick, and S. D. Hayward. 1989. Responsiveness of the Epstein-Barr virus NotI repeat promoter to the $\mathrm{Z}$ transactivator is mediated in a cell-type-specific manner by two independent signal regions. J. Virol. 63:3040-3050.

43. Manet, E., H. Gruffat, M. C. Trescol-Biemont, N. Moreno, P Chambard, J. F. Giot, and A. Sergeant. 1989. Epstein-Barr virus bicistronic mRNAs generated by facultative splicing code for two transcriptional trans-activators. EMBO J. 8:1819-1826.

44. Marschall, M., U. Leser, R. Seibl, and H. Wolf. 1989. Identification of proteins encoded by Epstein-Barr virus trans-activator genes. J. Virol. 63:938-942.

45. Miller, G. 1990. Epstein-Barr virus: biology, pathogenesis, and medical aspects, p. 1921-1958. In B. N. Fields, D. M. Knipe, R. M. Chanock, M. S. Hirsch, J. L. Melnick, T. P. Monath, and B. Roizman (ed.), Virology. Raven Press, New York.

46. Muesing, M. A., D. H. Smith, and D. J. Capon. 1987. Regulation of mRNA accumulation by a human immunodeficiency virus trans-activator protein. Cell 48:691-701.

47. Nabel, G., and D. Baltimore. 1987. An inducible transcription factor activates expression of human immunodeficiency virus in $\mathrm{T}$ cells. Nature (London) 326:711-713.

48. Narayanan, R., J. F. Klement, S. M. Ruben, K. A. Higgins, and C. A. Rosen. 1992. Identification of a naturally occurring transforming variant of the p65 subunit of NF-кB. Science 256:367-370.

49. Nelsen, B., L. Hellman, and R. Sen. 1988. The NF-kB-binding site mediates phorbol ester-inducible transcription in nonlymphoid cells. Mol. Cell. Biol. 8:3526-3531.

50. Neri, A., C. C. Chang, L. Lombardi, M. Salina, P. Corradini, A. T. Maiolo, R. S. Chaganti, and R. Dalla-Favera. 1991. B cell lymphoma-associated chromosomal translocation involves candidate oncogene lyt-10, homologous to NF-kB p50. Cell 67:1075-1087.

51. Nolan, G. P., and D. Baltimore. 1992. The inhibitory ankyrin and activator Rel proteins. Curr. Opin. Genet. Dev. 2:211-220.

52. Nolan, G. P., S. Ghosh, H. C. Liou, P. Tempst, and D. Baltimore. 1991. DNA binding and IкB inhibition of the cloned p65 subunit of NF-кB, a rel-related polypeptide. Cell 64:961-969.

53. Quinlivan, E. B., E. A. Holley-Guthrie, M. Norris, D. Gutsch, S. L. Bachenheimer, and S. C. Kenney. 1993. Direct BRLF1 binding is required for cooperative BZLF1/BRLF1 activation of the EpsteinBarr virus early promoter, BMRF1. Nucleic Acids Res. 21:1999_ 2007.

54. Riviere, Y., V. Blank, P. Kourilsky, and A. Israel. 1991. Processing of the precursor of NF- $\mathrm{KB}$ by the HIV-1 protease during acute infection. Nature (London) 350:625-626.

55. Rong, B. L., T. A. Libermann, K. Kogawa, S. Ghosh, L. X. Cao, L. D. Pavan, and E. C. Dunkel. 1992. HSV-1-inducible proteins bind to NF-kB-like sites in the HSV-1 genome. Virology 189:750756.

56. Rooney, C. M., D. T. Rowe, T. Ragot, and P. J. Farrell. 1989. The spliced BZLF1 gene of Epstein-Barr virus (EBV) transactivates an early EBV promoter and induces the virus productive cycle. J. Virol. 63:3109-3116.

57. Ruben, S. M., P. J. Dillon, R. Schreck, T. Henkel, C. H. Chen, M. Maher, P. A. Baeuerle, and C. A. Rosen. 1991. Isolation of a rel-related human cDNA that potentially encodes the $65-\mathrm{kD}$ subunit of NF-кB. Science 251:1490-1493.

58. Ruben, S. M., R. Narayanan, J. F. Klement, C. H. Chen, and C. A. Rosen. 1992. Functional characterization of the NF-кB p65 transcriptional activator and an alternatively spliced derivative. Mol. Cell. Biol. 12:444-454

59. Ryseck, R. P., P. Bull, M. Takamiya, V. Bours, U. Siebenlist, P. Dobrzanski, and R. Bravo. 1992. RelB, a new Rel family transcription activator that can interact with p50-NF-кB. Mol. Cell. Biol. 12:674-684.

60. Sassone-Corsi, P., A. Wildeman, and P. Chambon. 1985. A trans-acting factor is responsible for the simian virus 40 enhancer activity in vitro. Nature (London) 313:458-463.

61. Schule, R., and R. M. Evans. 1991. Cross-coupling of signal transduction pathways: zinc finger meets leucine zipper. Trends Genet. 7:377-381.

62. Sen, R., and D. Baltimore. 1986. Inducibility of $\kappa$ immunoglobulin enhancer-binding protein NF- $\mathrm{BB}$ by a posttranslational mechanism. Cell 47:921-928.

63. Sen, R., and D. Baltimore. 1986. Multiple nuclear factors interact with the immunoglobulin enhancer sequences. Cell 46:705-716.

64. Shimizu, N., S. Sakuma, Y. Ono, and K. Takada. 1989. Identification of an enhancer-type sequence that is responsive to $\mathrm{Z}$ and $\mathrm{R}$ trans-activators of Epstein-Barr virus. Virology 172:655-658.

65. Sista, N. D., J. S. Pagano, W. Liao, and S. Kenney. 1993. Retinoic acid is a negative regulator of the Epstein-Barr virus protein (BZLF1) that mediates disruption of latent infection. Proc. Natl. Acad. Sci. USA 90:3894-3898.

66. Sixbey, J. W., J. C. Nedrud, N. Raab-Traub, R. A. Hanes, and J. S. Pagano. 1984. Epstein-Barr virus replication in oropharyngeal epithelial cells. N. Engl. J. Med. 310:1225-1230.

67. Stein, B., P. C. Cogswell, and A. S. Baldwin. 1993. Functional and physical associations between NF- $\mathrm{KB}$ and C/EBP family members: a Rel domain-bZIP interaction. Mol. Cell. Biol. 13:3964-3974.

68. Stein, B., H. J. Rahmsdorf, A. Steffen, M. Litfin, and P. Herrlich. 1989. UV-induced DNA damage is an intermediate step in UV-induced expression of human immunodeficiency virus type 1 , collagenase, c-fos, and metallothionein. Mol. Cell. Biol. 9:51695181 .

69. Steward, R. 1987. Dorsal, an embryonic polarity gene in Drosophila is homologous to the vertebrate proto-oncogene, c-rel. Science 238:692-694.

70. Takada, K., N. Shimizu, S. Sakuma, and Y. Ono. 1986. trans activation of the latent Epstein-Barr virus (EBV) genome after transfection of the EBV DNA fragment. J. Virol. 57:1016-1022.

71. Urier, G., M. Buisson, P. Chambard, and A. Sergeant. 1989. The Epstein-Barr virus early protein EB1 activates transcription from different responsive elements including AP-1 binding sites. EMBO J. 8:1447-1453.

72. Walker, W. H., B. Stein, P. A. Ganchi, J. A. Hoffman, P. A. Kaufman, D. W. Ballard, M. Hannink, and W. C. Greene. 1992. The v-rel oncogene: insights into the mechanism of transcriptional activation, repression, and transformation. J. Virol. 66:5018-5029.

73. Wilhelmsen, K. C., K. Eggleton, and H. M. Temin. 1984. Nucleic acid sequences of the oncogene $\mathrm{v}$-rel in reticuloendotheliosis virus strain $\mathrm{T}$ and its cellular homolog, the proto-oncogene c-rel. $\mathrm{J}$. Virol. 52:172-182.

74. Young, L. S., R. Lau, M. Rowe, G. Niedobitek, G. Packham, F. Shanahan, D. T. Rowe, D. Greenspan, J. S. Greenspan, A. B. Rickinson, and P. J. Farrell. 1991. Differentiation-associated expression of the Epstein-Barr virus BZLF1 transactivator protein in oral hairy leukoplakia. J. Virol. 65:2868-2874.

75. Zalani, S., E. A. Holley-Guthrie, D. E. Gutsch, and S. C. Kenney. 1992. The Epstein-Barr virus immediate-early promoter BRLF1 can be activated by the cellular Sp1 transcription factor. J. Virol. 66:7282-7289.

76. Zhang, Q., D. Gutsch, and S. Kenney. 1994. Functional and physical interaction between p53 and BZLF1: implications for Epstein-Barr virus latency. Mol. Cell. Biol. 14:1929-1938.

77. zur Hausen, H., F. J. O'Neill, and K. F. Ulrich. 1978. Persisting oncogenic herpesvirus induced by the tumour promoter TPA Nature (London) 272:373-375. 